\title{
A New "D-Estimation Method" for Estimating Phase, Frequency, and Amplitude of Frequency-Varying Single-Phase Signals
}

\author{
Shinji Shinnaka Member (Kanagawa University, shinnaka@kanagawa-u.ac.jp)
}

Keywords: single phase, phase estimation, frequency estimation, amplitude estimation, frequency-varying, D matrix

The phase, frequency, and amplitude of single-phase voltages are the most important and basic information required for singlephase grid connected applications. This paper proposes a new "D-estimation method" for instantly and adaptively estimating the phase, frequency, and amplitude of frequency-varying single-phase signals in such applications. The D-estimation method has the following attractive features: 1) it is a new filtering method using the D-filters; 2) it involves the use of only filters and can be easily designed; 3) even in hostile envelopments caused by a frequency variation, a phase jump, amplitude sag/swell, harmonic distortion, and/or contaminated noise, good instant estimates of the phase, frequency, and amplitude can be obtained; 4) it is simple, but can exhibit high performance similar to the "robust PLL method". This paper presents the D-estimation method together with the design rules in detail; the usefulness of the method is verified by performing extensive numerical experiments.

Fig. 1 shows an estimation system configuration based on the Destimation method. The system consists of three sub-systems-"Dfilter block", "estimate producer", and "low-pass filter". The Dfilter block, which consists of two D-filters, plays the most important role in producing two $2 \times 1$ vector signals $\boldsymbol{v}_{2}$ and $s \boldsymbol{v}_{2}$. The first component of the vector signal $\boldsymbol{v}_{2}$ is the fundamental component of the input scalar signal and the second one is $\pi / 2-\mathrm{rad}$ phase lead signal of the first component. The vector signal $s \boldsymbol{v}_{2}$ is a derivative of $\boldsymbol{v}_{2}$. Using the vector signals $\boldsymbol{v}_{2}$ and $s \boldsymbol{v}_{2}$, instant estimates of the phase, frequency, and amplitude of the scalar signal are obtained in a simple manner. The frequency estimate $\hat{\omega}_{\alpha}$ is processed by the low-pass filter $F_{\ell}(s)$ and is fed back to the D-filter block. This feedback loop provides the estimation system with the ability to track varying frequency.

Fig. 2 shows the estimation result for the case of a single-phase signal with an amplitude of unity and a frequency variation given by

$$
\omega_{\alpha}=100 \pi(1+0.1 \sin (20 t))
$$

The waveform data in (a) indicate, from the top, the actual phase (dash line), its estimate (solid line), and the value of phase errors multiplied by 20 ; and the data in (b) indicate the actual and estimated frequencies, and the estimated amplitude. It is observed that good estimates are obtained even for the varying frequency.

It is experimentally confirmed that even in hostile envelopments caused by a frequency variation, a phase jump, amplitude sag/swell, harmonic distortion, and/or contaminated noise, the proposed method can provides good instant estimates of the phase, frequency, and amplitude of single-phase signals. A detailed explanation of the D-estimation method and extensive experiment results are given in the paper.

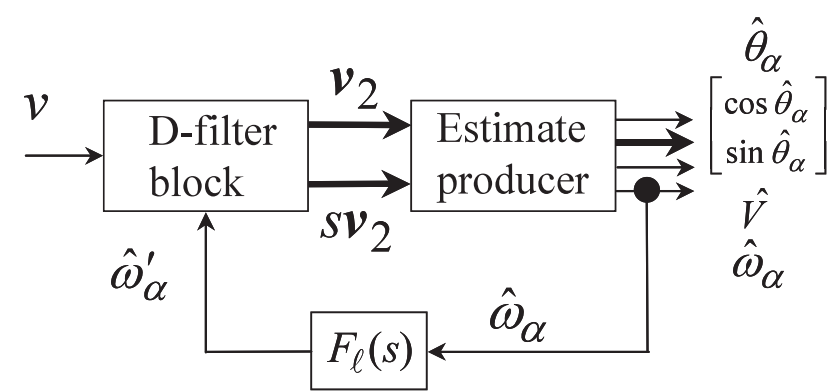

Fig. 1. Basic configuration of the proposed D-estimation system

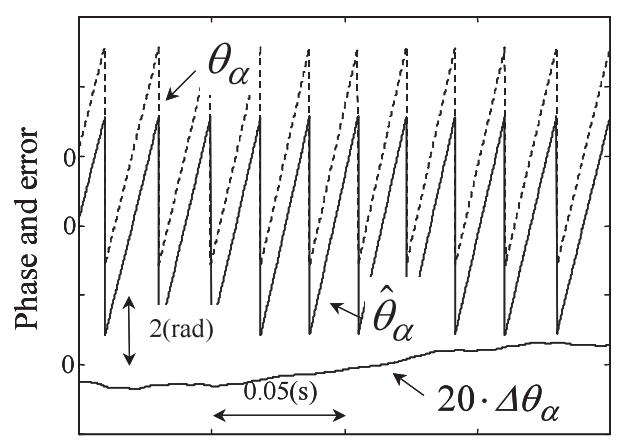

Time(s)

(a) Actual and estimated phases.

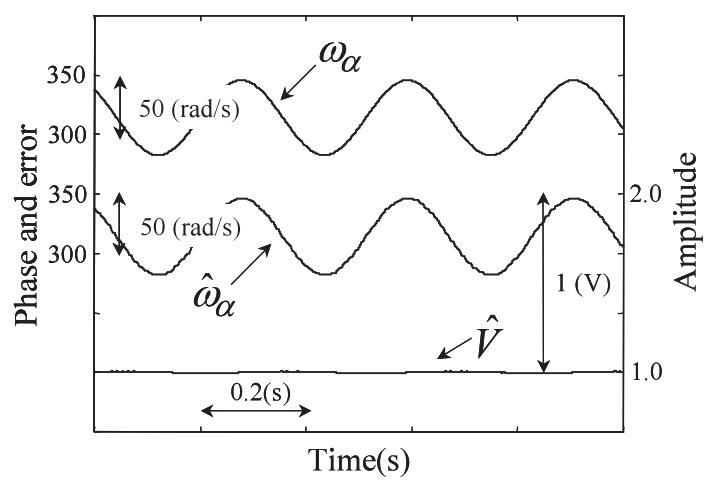

(b) Actual and estimated frequencies and estimated amplitude.

Fig. 2. Responses to a frequency-varying signal 


\title{
単相交流信号の基本波成分推定ための $\mathrm{D}$ 因子フィルタを用いた周波数追従形推定法
}

\author{
正 員 新中 新二*
}

\author{
A New "D-Estimation Method" for Estimating Phase, Frequency, and Amplitude of \\ Frequency-Varying Single-Phase Signals
}

Shinji Shinnaka*, Member

\begin{abstract}
The phase, frequency, and amplitude of single-phase voltages are the most important and basic information required for single-phase grid connected applications. This paper proposes a new "D-estimation method" for instantly and adaptively estimating the phase, frequency, and amplitude of frequency-varying single-phase signals in such applications. The D-estimation method has the following attractive features: 1) it is a new filtering method using the D-filters; 2) it involves the use of only filters and can be easily designed; 3) even in hostile envelopments caused by a frequency variation, a phase jump, amplitude sag/swell, harmonic distortion, and/or contaminated noise, good instant estimates of the phase, frequency, and amplitude can be obtained; 4) it is simple, but can exhibit high performance similar to the "robust PLL method". This paper presents the D-estimation method together with the design rules in detail; the usefulness of the method is verified by performing extensive numerical experiments.
\end{abstract}

キーワード : 単相, 位相推定, 周波数推定, 振幅推定, 周波数変動, D 因子

Keywords: single phase, phase estimation, frequency estimation, amplitude estimation, frequency-varying, D matrix

\section{1. はじめに}

単相電圧の基本波成分の位相，周波数（本論文では，近 年の慣習に従い, 角周波数を簡単に周波数と呼称する), 電 圧は, 交直変換器, UPS (Uninterruptible Power System), アクティブフィルタなどに代表される単相電力系統との連 系を前提とした電力変換・調整装置等においては, 最も基 本的な情報であり，これら情報の高精度な瞬時推定法が求 められている(1) (17)。また, 不平衡三相電圧の位相推定等に おいても, 単相電圧のための瞬時推定法が有用性であるこ とが指摘されている。

単相信号位相の瞬時推定法としては，フィードバック形 フィルタ法 ${ }^{(1)}$, 離散フーリエ変換（Discrete Fourier Trans-

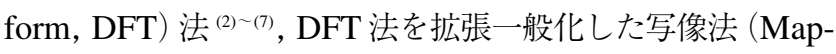
ping Method) (2), ヒルベルト変換 (Hilbert Transform) 法 ${ }^{(8)}$, PLL（Phase-Locked Loop）法 ${ }^{(9) \sim(17)}$ などが知られている。 これらの中で, 変動する周波数をも推定し得る潜在能力を 有していると期待されているのが PLL 法であり (9) (17), 事 実，周波数変動に対する追従性能に加えて，位相跳躍に対

\footnotetext{
*神奈川大学工学部電子情報フロンティア学科

干 221-8686 横浜市神奈川区六角橋 3-27-1

Dept. of Electrical Engineering, Kanagawa University

3-27-1, Rokkakubashi, Kanagawaku, Yokohama 221-8686
}

する追従性能, 振幅変動に対する追従性能, 信号歪みに対 する性能，ノイズ抑圧の性能を兼備したロバスト PLL 法が 最近になって新中により提案されている ${ }^{(17)}$ 。PLL 法以外の 従来推定法は, 周波数が一定であることを原理的条件とし ており，周波数変動に対する追従性能は基本的に備えてい ない(1) (8)。

本論文は, 単相信号の瞬時位相推定法として, 周波数変動 に対する追従性能を備えた，しかしPLLに依らない, 新た な 1 方法を提案するものである。提案法は, フィードバッ クフィルタ法, 写像法と同様に, フィードバック形フィルタ によるフィルタリングと言う簡単な原理に基づくものであ る。推定原理をフィルタリングに置く場合, 単相信号の変 動周波数に追従して, 周波数特性を支配するフィル夕係数 を自動調整する必要がある。しかし, 従来のフィードバッ クフィルタ法, 写像法においては, 高次フィルタにこの種の 追従的自動調整機能を付与することは大変困難である。本 論文では，フィードバック形フィルタとしてD因子フィル 夕を活用することにより, 本問題を解決した。D因子フィ ルタは,「周波数特性は, 1 つの外部スカラ信号によって, 瞬 時かつ線形的に変化することができる」と言った特長を具 備している ${ }^{(18)}$ 。提案の D 因子フィルタを用いた推定法 (以 下，D因子推定法と呼称）によれば，簡単な原理に拠りな がらも, 周波数変動を伴う単相信号の位相, 周波数, 振幅 
を推定することができ，更にはロバスト PLL 法と総合的に 同等な実用性能を得ることができる。

本論文は, 以下のように構成されている。次の第 2 章で は, 単相信号の位相, 周波数, 振幅推定のための問題を定式 化する。第 3 章では, 提案推定法の要となる $\mathrm{D}$ 因フィル夕 を概説する。第 4 章では，先ず，D因子推定法をシステム として実現してこの全体概要を説明し，次に，システムを 構成する各種機器の詳細を説明する。この際, 各種機器に 付随した設計パラメータの設計法も具体的に示す。第 5 章 では, 定常性能, 周波数変動に対する追従性能, 位相跳躍 に対する追従性能，振幅変動に対する追従性能，信号歪み に対する性能，ノイズ抑圧の性能等の多角的視点から，提 案法の有用性を実験的に検証し，ロバスト PLL 法と総合的 に同等の実用性能が得られることを明らかにする。本検証 に際し，設計パラメータの設計例も示す。第 6 章で本論文 を総括する。

（注 1）本論文では, 混乱の生じない限り, 記号 $s$ をラプラ ス演算子または微分演算子として断り無く使用する。

\section{2. 問題の設定}

次式で表現される単相信号 $v$ を考える。

$$
v=V \sin \left(\omega_{\alpha} t+\phi_{\alpha}\right)+e
$$

(1) 式に扔ける基本波成分の周波数（以下，基本周波数と略 記） $\omega_{\alpha}$, 振幅 $V$ 及び位相 $\phi_{\alpha}$ は未知とする。ただし, 基本 周波数 $\omega_{\alpha}$ の概略的な上下限值 $\omega_{\alpha, \text { max }}, \omega_{\alpha, \text { min }}$ は既知とす る。また, $e$ は, 基本周波数 $\omega_{\alpha}$ の正弦信号として表現でき ないノイズ，高調波成分等とする。

ここで考える問題は, 単相信号 $v$ のを用いて, 同信号 の基本波成分の瞬時值である位相 $\theta_{\alpha}$

$$
\theta_{\alpha}=\omega_{\alpha} t+\phi_{\alpha}
$$

周波数 $\omega_{\alpha}$, 及び振幅 $V$ を実時間推定することである。

\section{D 因子フィルタ}

上記問題を解決するべく, 本論文が提案する D 因子推 定法に扔いては, 周波数特性の瞬時シフト機能を有する D 因子フィルタが重要な役割を演ずる。この点を考慮し，文 献(18) を参考に，D因子フィルタの要点を概説しておく。 実数の一定フィル夕係数をもつ次の 1 入力 1 出力 (以下, 1 入出力と略記） $\mathrm{n}$ 次安定フィルタ $F(s)$ を考える。

$$
F(s)=\frac{B(s)}{A(s)} \text {. }
$$
ただし，

$$
\begin{aligned}
& A(s)=s^{n}+a_{n-1} s^{n-1}+\cdots \cdots+a_{1} s+a_{0} \cdots \cdots \cdots \\
& B(s)=b_{n} s^{n}+b_{n-1} s^{n-1}+\cdots \cdots+b_{1} s+b_{0} \cdots \cdots
\end{aligned}
$$

上の 1 入出力フィルタと同一のフィルタ係数をもつ 2 入 出力 $2 \mathrm{n}$ 次 D 因子フィル夕 $\boldsymbol{F}\left(\boldsymbol{D}\left(s, \omega_{0}\right)\right)$ は, 次式のように 定義される。

$$
\begin{aligned}
\boldsymbol{F}\left(\boldsymbol{D}\left(s, \omega_{0}\right)\right) & =\boldsymbol{A}^{-1}\left(\boldsymbol{D}\left(s, \omega_{0}\right)\right) \boldsymbol{B}\left(\boldsymbol{D}\left(s, \omega_{0}\right)\right) \\
& =\boldsymbol{B}\left(\boldsymbol{D}\left(s, \omega_{0}\right)\right) \boldsymbol{A}^{-1}\left(\boldsymbol{D}\left(s, \omega_{0}\right)\right)
\end{aligned}
$$

ただし，

$$
\begin{aligned}
\boldsymbol{A}\left(\boldsymbol{D}\left(s, \omega_{0}\right)\right)= & \boldsymbol{D}^{n}\left(s, \omega_{0}\right)+a_{n-1} \boldsymbol{D}^{n-1}\left(s, \omega_{0}\right)+\cdots \cdots \\
& +a_{1} \boldsymbol{D}\left(s, \omega_{0}\right)+a_{0} \boldsymbol{I} \cdots \cdots \cdots \cdots(7) \\
\boldsymbol{B}\left(\boldsymbol{D}\left(s, \omega_{0}\right)\right)= & b_{n} \boldsymbol{D}^{n}\left(s, \omega_{0}\right)+b_{n-1} \boldsymbol{D}^{n-1}\left(s, \omega_{0}\right)+\cdots \cdots \\
& +b_{1} \boldsymbol{D}\left(s, \omega_{0}\right)+b_{0} \boldsymbol{I} \cdots \cdots \cdots \cdots(8)
\end{aligned}
$$

(6) （8）式における 2 行 2 列（以下, $2 \times 2$ と略記） $\boldsymbol{D}(\cdot, \cdot)$ が D 因子であり，以下のように定義されている。

$$
\boldsymbol{D}\left(s, \omega_{0}\right)=\left[\begin{array}{cc}
s & -\omega_{0} \\
\omega_{0} & s
\end{array}\right]=s \boldsymbol{I}+\omega_{0} \boldsymbol{J}
$$

ここに, $\boldsymbol{I}$ は $2 \times 2$ 単位行列であり, $\boldsymbol{J}$ は次の $2 \times 2$ 交代行 列であり，

$$
\boldsymbol{J}=\left[\begin{array}{cc}
0 & -1 \\
1 & 0
\end{array}\right]
$$

$\omega_{0}$ は外部から入力される実数スカラ信号である。

$2 \mathrm{n}$ 次 $\mathrm{D}$ 因子フィル夕は, 以下の魅力的な性質を有して いることが，解明されている(18)。

1) $\boldsymbol{F}\left(\boldsymbol{D}\left(s, \omega_{0}\right)\right)$ の安定度は, $F(s)$ と同一である。

2) $\boldsymbol{F}\left(\boldsymbol{D}\left(s, \omega_{0}\right)\right)$ を二相信号に適用する場合, この伝達特 性は, 正相信号に対しては $F\left(s+j \omega_{0}\right)$, 逆相信号に 対しては $F\left(s-j \omega_{0}\right)$ となる。この結果, $\boldsymbol{F}\left(\boldsymbol{D}\left(s, \omega_{0}\right)\right)$ は，二相信号に対し，周波数の絶対的大きさのみな らず，周波数の正負符号に応じた信号選択分離機能 をもつ。周波数特性は, 外部信号 $\omega_{0}$ によって, 瞬 時かつ線形的に変化する。

3) $\boldsymbol{F}\left(\boldsymbol{D}\left(s, \omega_{0}\right)\right)$ の実現は, 形式的に, $F(s)$ の実現におけ る $s$ を D因子 $\boldsymbol{D}\left(s, \omega_{0}\right)$ で置換し, かつスカラ信号を $2 \times 1$ ベクトル信号に置換することにより, 直ちに達成 される。この形式置換性は, $F(s)$ の構造如何によら ない。すなわち, $F(s)$ のすべての構造に適用される。 性質 2) から明白なように, $F(s)$ が所要のローパス特性 をもつようにこれを設計すれば，対応の D 因子フィル夕 $\boldsymbol{F}\left(\boldsymbol{D}\left(s, \omega_{0}\right)\right)$ は, 周波数 $\omega_{0}$ の正相信号あるいは逆相信号に 対して位相遅れのない所要のバンドパス特性をもつことに なる。すなわち，本 D 因子フィル夕によれば，位相遅れの ない状態でこれら信号を他信号から分離抽出することがで きる。しかも, $\omega_{0}$ に応じて, バンドパス特性の中心周波数 は, 瞬時かつ線形的に変更することができる。D 因子フィ ル夕の本特性は, 可変周波数の正相信号あるいは逆相信号 の抽出に, 特に好適な特性である。

D 因子フィルタの実現の形式は種々存在する。図 1(a)は, モジュールベクトル直接 I 形による D 因子フィルタの実現 を，3次フィルタリングを例に示した ${ }^{(18)}$ 。同図 (b) は, 同 実現にモジュール的に利用されているD 因子の逆行列の実 


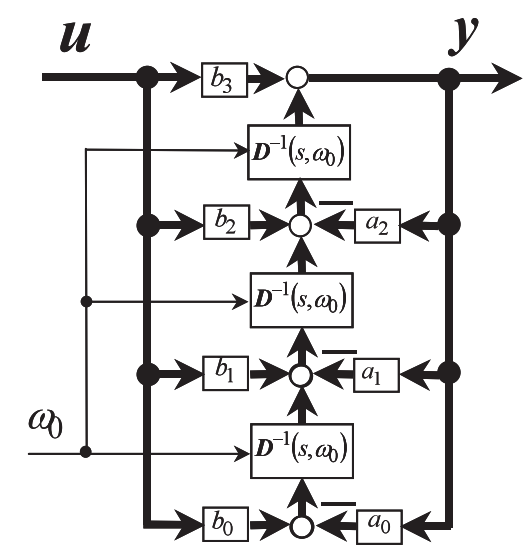

(a)

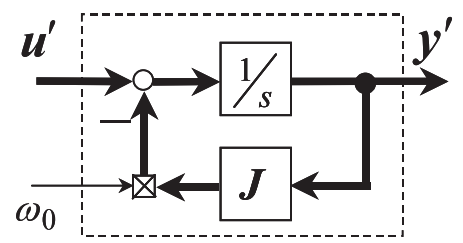

(b)

図 1 D 因子フィルタの実現例

Fig. 1. A realization example of D-filters.

現例である。両図における $\boldsymbol{u}, \boldsymbol{u}^{\prime}$ は $2 \times 1$ ベクトル入力で あり, $\boldsymbol{y}, \boldsymbol{y}^{\prime}$ は $2 \times 1$ ベクトル出力であり， $\omega_{0}$ は実数スカ ラ信号である。D 因子フィルタで処理される信号はべクト ル入力 $\boldsymbol{u}$ であり, 処理後の信号がベクトル出力 $\boldsymbol{y}$ である。 実数スカラ信号 $\omega_{0}$ は D 因子フィルタの特性を瞬時変化さ せる特性変更用の外部信号である。なお，記号凶は信号と 信号とを乗算するための乗算器である。以降では，乗算器 凶は，入力信号がスカラ信号とベクトル信号の場合にはス カラ信号によるベクトルの各要素との乗算を実行するべク トル乗算器を，入力信号が 2 個のベクトル信号の場合には 内積演算を遂行し結果をスカラ信号として出力する内積器 を意味するものとする。

\section{4. 推定システムの構成と設計}

$\langle\mathbf{4} \cdot \mathbf{1}\rangle \quad$ システムの全体構成＼cjkstart単相信号の位相，周波 数, 振幅を実時間推定のためのD 因子推定法を実現したシ ステム（以下，D因子推定システムと呼称）を図 2 に示す。 同システムは, 大きくは, D 因子フィルタブロック (D-filter block と表示), 推定值生成器 (estimate producer と表示), 及びローパスフィルタ $F_{\ell}(s)$ から構成されている。

$\mathrm{D}$ 因子フィルタブロックは，外部から単相信号 $v$ と同信 号の周波数推定值 (フィルタ処理後の信号) $\hat{\omega}_{\alpha}^{\prime}$ を受け取り, この基本波近似成分の余弦正弦值を要素とする $2 \times 1$ ベク トル信号 $\boldsymbol{v}_{2}$ 及び同微分值 $s \boldsymbol{v}_{2}$ を生成している。すなわち，

$$
\begin{aligned}
& \boldsymbol{v}_{2}=\left[\begin{array}{l}
v_{2 \alpha} \\
v_{2 \beta}
\end{array}\right] \approx V\left[\begin{array}{l}
\cos \theta_{\alpha} \\
\sin \theta_{\alpha}
\end{array}\right] \ldots \ldots . \\
& s \boldsymbol{v}_{2}=s\left[\begin{array}{l}
v_{2 \alpha} \\
v_{2 \beta}
\end{array}\right] \approx \frac{d}{d t} V\left[\begin{array}{c}
\cos \theta_{\alpha} \\
\sin \theta_{\alpha}
\end{array}\right] .
\end{aligned}
$$

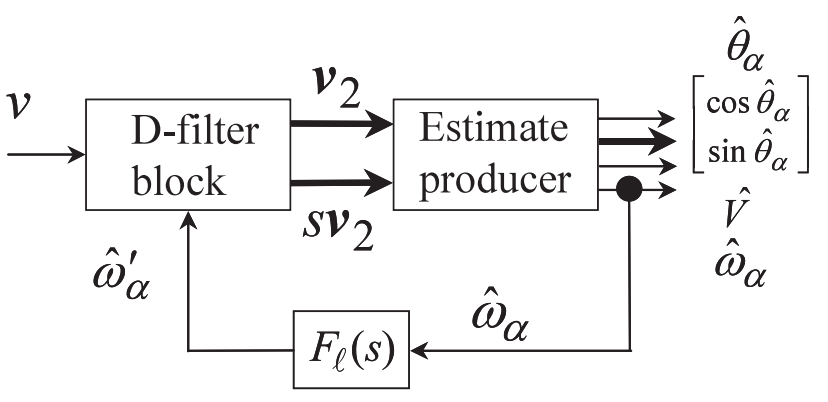

図 $2 \mathrm{D}$ 因子推定システムの基本構造

Fig. 2. A basic configuration of the proposed Destimation system.

推定值生成器は入力信号として $v_{2}, s v_{2}$ を受け取り, 位 相推定值 $\hat{\theta}_{\alpha}$, 同余弦正弦值 $(2 \times 1$ ベクトル信号 $)$, 振幅推 定值 $\hat{V}$, 周波数推定值 $\hat{\omega}_{\alpha}$ を算定し出力している。これら 出力信号が，本問題の解答たる信号である。

周波数推定值 $\hat{\omega}_{\alpha}$ はローパスフィルタ処理され, フィル 夕処理後の周波数推定值 $\hat{\omega}_{\alpha}^{\prime}$ は D 因子フィルタブロックヘ フィードバックされている。フィードバックされた周波数推 定值 $\hat{\omega}_{\alpha}^{\prime}$ は, 後述するように, ブロック内の D 因子フィルタ における外部スカラ信号 $\omega_{0}$ として使用される(図 1 参照)。

既に説明したように，D因子フィルタの特性は，外部か ら入力されるスカラ信号 $\omega_{0}$ に応じて, その周波数特性を 線形的に変化する。外部スカラ信号 $\omega_{0}$ として周波数推定 值 $\hat{\omega}_{\alpha}^{\prime}$ を利用する D 因子フィルタは, 周波数推定值に従い, 周波数特性を変化することになる。提案推定システムでは, 実験を通じ確認するように,「周波数推定 $\rightarrow \mathrm{D}$ 因子フィル 夕による周波数特性の自動調整 $\rightarrow$ 周波数推定」と言った フィードバックが起き, 提案推定システムは周波数変動が ある場合にも周波数等を適切に推定できるようになる。以 下, 上述の 3 主要機器に関し, その詳細を個別に説明する。

〈4·2〉D 因子フィルタブロック

\section{A. 全体構成}

D 因子フィルタブロックの概略構成を，図 3(a) に示した。 同図より明白なように，本ブロックは，直列結合された 2 個のD 因子フィル夕 $\boldsymbol{F}_{1}\left(\boldsymbol{D}\left(s,-\hat{\omega}_{\alpha}^{\prime}\right)\right), \boldsymbol{F}_{2}\left(\boldsymbol{D}\left(s,-\hat{\omega}_{\alpha}^{\prime}\right)\right)$ によ り構成されている。これら D 因子フィルタに対応した 1 入 出力フィルタ $F_{1}(s), F_{2}(s)$ は共にローパスフィルタである ((3) 式参照)。

B. 前段フィルタ

$\mathrm{D}$ 因子フィルタは, 元来, 2 入出力フィルタであるが, 前 段の $\mathrm{D}$ 因子フィルタでは, 入力第 1 要素 ( $\alpha$ 要素) は出力 第 1 要素 ( $\alpha$ 要素) そのものとしている。本フィードバッ クにより, 前段 $\mathrm{D}$ 因子フィルタは 1 入力 2 出力フィルタと して働いている。このときのスカラ入力は, (1) 式に定義さ れた単相信号である。本構成では，2 個の出力は, 単相信 号 $v$ の基本波成分に対し, その主成分が基本波成分の周波 数と同一でかつ位相が $\pi / 2(\mathrm{rad})$ だけ進んだ信号（以下，矩 相信号と呼称) $v_{1 \alpha}$ と, その主成分が同周波数と同一でかつ 


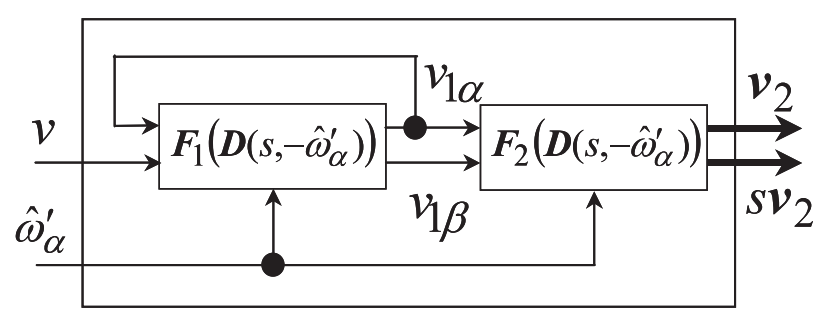

(a)

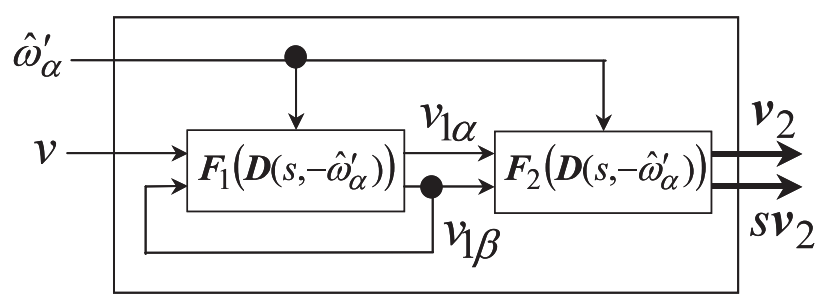

(b)

図 3 D 因子フィルタブロックの概略構成

Fig. 3. Configuration of D-filter block.

位相が同相の信号 (以下, 同相信号と呼称) $v_{1 \beta}$ となる。換 言するならば， 2 個の出力は 1 対の二相信号となる。

以下に代表的な例を示す。次の 1 入出力の 1 次ローパス フィルタ $F_{1}(s)$ を考える。

$$
F_{1}(s)=\frac{a_{1,0}}{s+a_{1,0}} ; a_{1,0}=\text { const }>0 \text {. }
$$

(12) 式に対応した 2 入出力 D 因子フィルタとして, 周波 数 $\hat{\omega}_{\alpha}^{\prime}>0$ の正相信号に対してバンドパス特性をもつ (13) 式を考える。

$$
\begin{gathered}
\boldsymbol{F}_{1}\left(\boldsymbol{D}\left(s,-\hat{\omega}_{\alpha}^{\prime}\right)\right)=\left[\boldsymbol{D}\left(s,-\hat{\omega}_{\alpha}^{\prime}\right)+a_{1,0} \boldsymbol{I}\right]^{-1} a_{1,0} \\
; a_{1,0}=\mathrm{const}>0, \hat{\omega}_{\alpha}^{\prime}>0 \ldots \ldots \ldots \ldots
\end{gathered}
$$

眓 3(a) の入出力関係を (13) 式の D 因子フィルタに適用 するならば, 次式が得られる。

$$
\left[\boldsymbol{D}\left(s,-\hat{\omega}_{\alpha}^{\prime}\right)+a_{1,0} \boldsymbol{I}\right]\left[\begin{array}{l}
v_{1 \alpha} \\
v_{1 \beta}
\end{array}\right]=a_{1,0}\left[\begin{array}{c}
v_{1 \alpha} \\
v
\end{array}\right] \ldots \ldots \ldots \ldots
$$

これより，

$$
\left[\boldsymbol{D}\left(s,-\hat{\omega}_{\alpha}^{\prime}\right)+\left[\begin{array}{cc}
0 & 0 \\
0 & a_{1,0}
\end{array}\right]\right]\left[\begin{array}{l}
v_{1 \alpha} \\
v_{1 \beta}
\end{array}\right]=a_{1,0}\left[\begin{array}{l}
0 \\
v
\end{array}\right]
$$

(15) 式を $v_{1 \alpha}, v_{1 \beta}$ について整理すると, 次の関係式を得る。

$$
\left.\begin{array}{c}
\frac{v_{1 \alpha}}{v}=G_{\alpha}(s)=\frac{-\hat{\omega}_{\alpha}^{\prime}}{s} G_{\beta}(s) \\
\frac{v_{1 \beta}}{v}=G_{\beta}(s)=\frac{a_{1,0} s}{s^{2}+a_{1,0} s+\hat{\omega}_{\alpha}^{\prime 2}}
\end{array}\right\}
$$

(16) 式における第 1 式，第 2 式の伝達関数は，基本周波 数 $\hat{\omega}_{\alpha}^{\prime}$ を持つスカラ入力信号 $v$ に対する矩相信号, 同相信 号の生成特性を示している。矩相信号用伝達関数は同相信 号用伝達関数に純粋積分を施したものとなっており，矩相 信号は符号反転により同相信号に対し $\pi / 2(\mathrm{rad})$ の位相進み を得ている。なお，(15) 式におけるフィル夕係数 $a_{1,0}$ は常
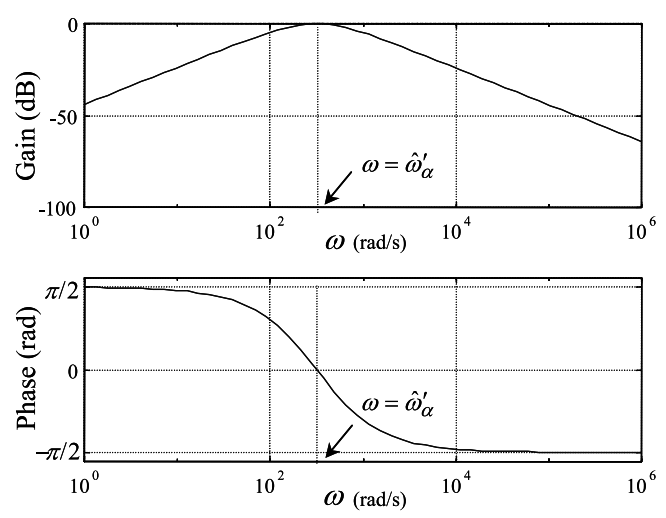

図 4 同相信生成用伝達関数の周波数応答例

Fig. 4. Frequency response example of filter producing in-phase signal.

時一定である。

同相信号を生成する (16) 式第 2 式伝達関数に関し, 条件 $a_{1,0}=628, \hat{\omega}_{\alpha}^{\prime}=314$ の下に, その周波数特性を図 4 に示 した。図 4 より, 同相信号生成用の伝達関数は $\hat{\omega}_{\alpha}^{\prime}$ を心 周波数とするバンドパス特性をもつことが明白である。

前段フィルタの第 1 義的目的は, 矩相信号と同相信号か らなる二相信号の生成にあり, 元の単相信号 $v$ に含まれる 高調波, 高周波ノイズの除去は, 第 2 義的目的である。元 来の目的を考慮するならば, 前段フィル夕は必ずしも高次 に選定する必要がなく, 1 次フィルタリング用の (13) 式で 所期の目的を達成できる。

(13) 式におけるフィルタ係数の選定指針は以下の通りで ある。

$$
a_{1,0}=\varsigma \frac{\omega_{\alpha, \max }+\omega_{\alpha, \min }}{2}=\mathrm{const} ; 0<\varsigma \leq 2 \ldots \ldots
$$

基本周波数真值 $\omega_{\alpha}$ の概略的推定值は，この既知の上下限 值 $\omega_{\alpha, \max }, \omega_{\alpha, \min }$ の平均值とするのが合理的であり，(17a) 式は，この考えに基づきフィル夕係数を定めている。また， $0<\varsigma \leq 2$ は, 図 4 に示したようなバンドパス特性を得る ための条件である。

前段フィルタで, 入力された単相信号の周波数変動, 位 相変動, 振幅変動を速やかに反映した二相信号を生成する には，速応性が特に重要である。本論文では，この点を考 慮し, フィルタ係数としては, 平均的に最高の速応性が期 待される $\varsigma=2$ の選定を特に推奨する。基本周波数の概略 推定值が同真值 $\omega_{\alpha}$ に等しく, 更には $\hat{\omega}_{\alpha}^{\prime}=\omega_{\alpha}$ の場合には, (16) 式における伝達関数の極の実数部は $\varsigma=2$ の下で最小 負值となり，ひいては最高の速応性が得られる。本選定の 下では，(17a) 式は，次式のように整理される。

$$
a_{1,0}=\omega_{\alpha, \max }+\omega_{\alpha, \min }
$$

(注 2) (1), (2) 式は, 単相信号を正弦信号として捕らえ, こ の位相を推定するものである。これに対して, 次式 のように，単相信号を余弦信号として捕らえ，この 位相を推定することもある。 
$v=V \cos \left(\omega_{\alpha} t+\phi_{\alpha}\right)+e=V \cos \left(\theta_{\alpha}\right)+e$

この場合の前段フィルタの構成は図 3(b) となり,

式に対応した伝達関数は次式となる。

$$
\left.\begin{array}{l}
\frac{v_{1 \alpha}}{v}=G_{\alpha}(s)=\frac{a_{1,0} s}{s^{2}+a_{1,0} s+\hat{\omega}_{\alpha}^{\prime 2}} \\
\frac{v_{1 \beta}}{v}=G_{\beta}(s)=\frac{\hat{\omega}_{\alpha}^{\prime}}{s} G_{\alpha}(s)
\end{array}\right\}
$$

\section{C. 後段フィルタ}

D 因子フィルタブロックにおける後段フィルタの役割は, 二相信号 $v_{1 \alpha}, v_{1 \beta}$ に含まれる高調波成分，高周波ノイズを 除去し, 基本波成分のみからなる二相正相信号 $v_{2 \alpha}, v_{2 \beta}$ と 同微分值を抽出することにある。本 D 因子フィル夕設計の ための 1 入出力フィルタとしては, 次の $\mathrm{n}$ 次ローパスフィ ルタを考える。

$$
\begin{aligned}
F_{2}(s) & =\frac{B_{2}(s)}{A_{2}(s)} \\
& =\frac{b_{2, n-1} s^{n-1}+\cdots+b_{2,1} s+b_{2,0}}{s^{n}+a_{2, n-1} s^{n-1}+\cdots \cdots+a_{2,1} s+a_{2,0}}
\end{aligned}
$$

(18) 式においては, 常に, 分子多項式の次数は分母多項式 の次数以下である点には注意されたい。分母の次数は，多 くの場合，高くとも 3 次で十分である。

周波数 $\hat{\omega}_{\alpha}^{\prime}>0$ の正相信号に対してバンドパス特性を発 揮し逆相信号を含め他の信号成分を排除する (18) 式に対応 したD 因子フィルタは次式となる。

$$
\begin{aligned}
\boldsymbol{F}_{2}\left(\boldsymbol{D}\left(s,-\hat{\omega}_{\alpha}^{\prime}\right)\right) & =\boldsymbol{A}_{2}^{-1}\left(\boldsymbol{D}\left(s,-\hat{\omega}_{\alpha}^{\prime}\right)\right) \boldsymbol{B}_{2}\left(\boldsymbol{D}\left(s,-\hat{\omega}_{\alpha}^{\prime}\right)\right) \\
& =\boldsymbol{B}_{2}\left(\boldsymbol{D}\left(s,-\hat{\omega}_{\alpha}^{\prime}\right)\right) \boldsymbol{A}_{2}^{-1}\left(\boldsymbol{D}\left(s,-\hat{\omega}_{\alpha}^{\prime}\right)\right)
\end{aligned}
$$

上式における $\boldsymbol{A}_{2}(\cdot), \boldsymbol{B}_{2}(\cdot)$ の定義は，(7)，(8) 式と同様で ある。

(19) 式の D 因子フィル夕の実現は，簡単には，図 1 に示 したモジュールベクトル直接 I 形を利用すればよい。図 5 は，フィルタの最終段におけるD 因子逆行列の実現の様子 を示したものである。眓 5 より理解されるように，本 D 因 子フィルタでは，フィルタ処理後の二相正相信号 $v_{2 \alpha}, v_{2 \beta}$ に加えて, これらの微分信号も, 特別の演算負担の要なく, 同時に抽出することができる。本特性には，注意されたい。

(19) 式の D 因子フィルタの係数 $a_{2, i}, b_{2, i}$ は, (18) 式の 1 入出力フィルタ $F_{2}(s)$ の設計を通じ定めることになる。ロー パスフィルタ $F_{2}(s)$ は，この帯域幅 $\omega_{2 c}$ の指定を通じ設計 できる。設計例は第 5 章の実験検証の際に示す。

(注 3) D 因子フィルタブロックにおける前段フィルタを高 次フィルタとして設計する場合には，後段フィルタ を撤去することも可能である。

$\langle\mathbf{4} \cdot \mathbf{3}\rangle$ 推定值生成器推定值生成器は, 後段フィル 夕の出力信号 $\boldsymbol{v}_{2}, \quad s \boldsymbol{v}_{2}$ を入力信号として受け取り，これら を用いて，簡単な原理により，振幅推定值 $\hat{V}$, 位相推定值 $\hat{\theta}_{\alpha}$, 同余弦正弦值 $(2 \times 1$ ベクトル信号 $)$, 周波数推定值 $\hat{\omega}_{\alpha}$

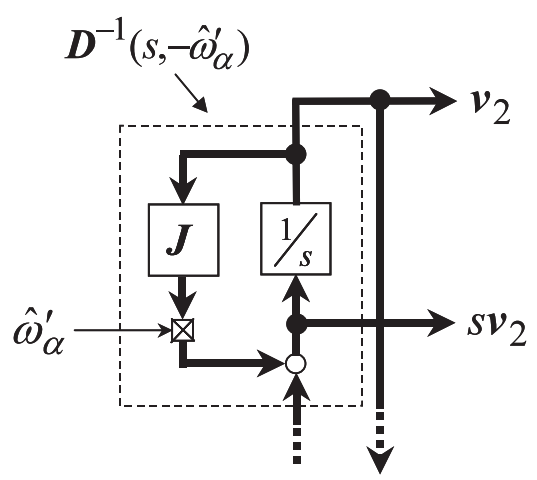

図 5 D 因子フィルタの最終段の構成例

Fig. 5. Configuration example of the D-module at the last stage of D-filters.

を算定し出力している。以下にこの要点を説明する。

\section{A. 振幅の推定}

提案推定システムでは，フィル夕処理信号 $\boldsymbol{v}_{2}$ のノルム計 算を通じて，単相信号基本波成分の振幅を推定している。 すなわち，

$$
\hat{V}=\left\|\boldsymbol{v}_{2}\right\|
$$

\section{B. 位相の推定}

提案推定システムでは, フィルタ処理信号 $\boldsymbol{v}_{2}$ が得られた ならば，この要素を用いた逆正接処理を通じ, 位相推定值 を定めている。すなわち，

$$
\hat{\theta}_{\alpha}=\tan ^{-1} \frac{v_{2 \beta}}{v_{2 \alpha}}
$$

\section{C. 位相余弦正弦值と同微分值の推定}

提案推定システムでは, フィルタ処理後の 2 信号 $\boldsymbol{v}_{2}, s \boldsymbol{v}_{2}$ を振幅推定值で正規化することにより，位相の余弦正弦值 と同微分值を生成している。すなわち，

$$
\begin{aligned}
& {\left[\begin{array}{c}
\cos \hat{\theta}_{\alpha} \\
\sin \hat{\theta}_{\alpha}
\end{array}\right]=\frac{\boldsymbol{v}_{2}}{\left\|\boldsymbol{v}_{2}\right\|}=\frac{\boldsymbol{v}_{2}}{\hat{V}} \cdots} \\
& s\left[\begin{array}{c}
\cos \hat{\theta}_{\alpha} \\
\sin \hat{\theta}_{\alpha}
\end{array}\right]=\frac{\boldsymbol{s} \boldsymbol{v}_{2}}{\left\|\boldsymbol{v}_{2}\right\|}=\frac{\boldsymbol{s} \boldsymbol{v}_{2}}{\hat{V}}
\end{aligned}
$$

以降では，(22) 式の位相余弦正弦值（すなわち，2×1ベ クトル信号）を位相ベクトルと呼称する。単相信号基本波 成分の位相推定值を利用する応用では，位相推定值そのも のではなく，位相推定值による位相べクトルを必要とする ことが少なくない。この種の応用では, (21) 式の位相推定 は必要なく, (22) 式の位相べクトルこそが有用である。こ の点を考慮して, 図 2 の D 因子推定システムでは, 位相べ クトルの出力の様子も示した。

\section{D. 周波数の推定}

提案の推定システムでは, 位相ベクトルと同微分值と用い た次の簡単な積和演算により，基本周波数を推定している。

$$
\hat{\omega}_{\alpha}=\operatorname{Lmt}\left(\frac{\left(s \boldsymbol{v}_{2}\right)^{T} \boldsymbol{J} \boldsymbol{v}_{2}}{\left\|\boldsymbol{v}_{2}\right\|^{2}}\right) .
$$




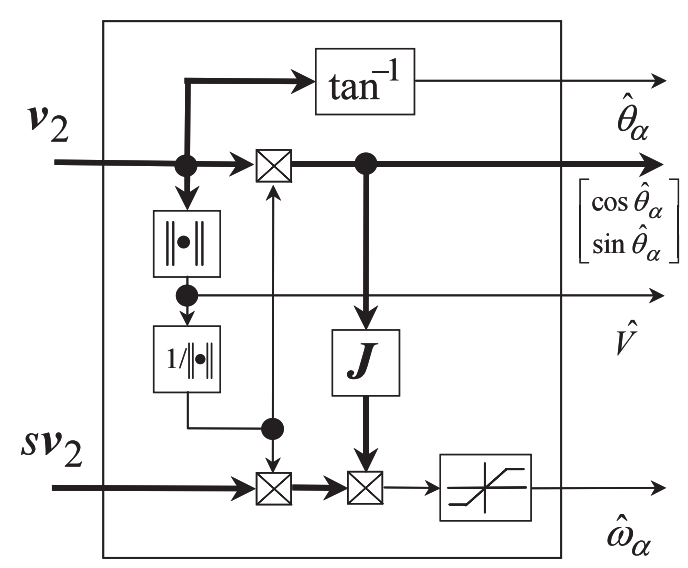

図 6 推定值生成器の構成例

Fig. 6. A configuration of estimate producer.

ここに $\operatorname{Lmt}(\cdot)$ はリミッタを意味する。本リミッタの上下 限值には，既知の大きめな概略值を設定すればよい。

図 6 に, 上記原理に忠実に従った位相推定值生成器の内 部構造を示した。なお，周波数推定値 $\hat{\omega}_{\alpha}$ は，(24) 式に代 わって，(21) 式の位相推定值 $\hat{\theta}_{\alpha}$ を近似微分し得てもよい。

〈4・4〉 ローパスフィルタローパスフィルタ $F_{\ell}(s)$ の 目的は, 周波数推定值 $\hat{\omega}_{\alpha}$ に含まれる高周波成分を除去し, D 因子フィルタブロックに使用されるスカラ信号を生成す ることである。本ローパスフィル夕は，基本的には，次の 1 次フィルタでよい。

$$
F_{\ell}(s)=\frac{\omega_{\ell c}}{s+\omega_{\ell c}} .
$$

本フィルタの带域幅 $\omega_{\ell c}$ は，その目的より明白なように, D 因子フィル夕の帯域幅 $\omega_{2 c}$ を用いた次の関係式を満足する ように設計すればよい。

$\omega_{\ell c} \leq \omega_{2}$

\section{5. 数值実験}

提案の D 因子推定法の性能を確認すべく，数值実験を 行った。図 2 に示した D 因子推定システムの実現は，マイ コンあるいはDSP を利用した離散時間実現が実際的であ る。システムの離散時間実現を考慮するならば，数值実験 によるシステム性能の検証は，十分に実際的である。

実験項目は，文献(17) で提示・公開されたロバスト PLL システム（ロバスト PLL 法を実現したシステム）と同一と した。これにより，D因子推定法の推定性能の把握に加え， ロバスト PLL 法との相対的な性能の把握も可能となる。 D 因子推定法の最大の特徵は周波数変動に対する追従機能を 有する点あり, 従来推定法の中で本機能を有するのが PLL 法である。ロバスト PLL 法は, PLL 法の中で最高レベル の性能を有することが知られている(17)。

数值実験に際し，単相信号に関する概略的に既知な周波 数上下限值 $\omega_{\alpha, \max }, \omega_{\alpha, \min }$ は次の通りとした。

$$
\omega_{\alpha, \max }=110 \pi(\mathrm{rad} / \mathrm{s}), \quad \omega_{\alpha, \min }=90 \pi(\mathrm{rad} / \mathrm{s})
$$

これに対して，図 2 の D 因子推定システムを以下のように 構成した。

$\mathrm{D}$ 因子フィルタブロックの前段フィルタは，1 次フィル タリングの (12)，(13) 式に対応したものを考えた。また, 後段フィルタとしては，2次フィルタリングの次式に対応 したものを考えた。

$$
F_{2}(s)=\frac{B_{2}(s)}{A_{2}(s)}=\frac{\omega_{n}^{2}}{s^{2}+2 \omega_{n} s+\omega_{n}^{2}} \cdots
$$

上のフィルタに関しては, フィルタ係数 $\omega_{n}$ と带域幅 $\omega_{2 c}$ の 間には，次の関係が成立している。

$$
\omega_{n} \approx 1.55 \omega_{2 c}
$$

また，ローパスフィルタ $F_{\ell}(s)$ は，(25) 式のものを使用し た。なお，離散時間実現のためのサンプリング周期 $T_{s}$ は, 文献(17)のロバストPLL システムと性能比較を考慮し, こ れと同一の $T_{s}=0.0001(\mathrm{~s})$ とした。

$\langle\mathbf{5} \cdot \mathbf{1}\rangle$ 定常性能 基本的にして最重要性能の 1 つで ある定常時の推定性能を確認すべく, (1) 式の単相信号に次 の理想的条件を付した ${ }^{(17)}$ 。

$$
\omega_{\alpha}=100 \pi=\text { const }, \quad \phi_{\alpha}=0, \quad e=0 \ldots
$$

これに対する D 因子フィルタブロック，ローパスフィル 夕 $F_{\ell}(s)$ の設計パラメー夕は, (17b), (25b), (26) 式に従い, 以下のように定めた。

$$
\left.\begin{array}{l}
a_{1,0}=200 \pi, \quad \omega_{2 c}=200, \\
\omega_{n}=1.55 \omega_{2 c}=310, \quad \omega_{\ell c}=\omega_{2 c}=200
\end{array}\right\} \cdots \cdots
$$

なお, D 因子フィルタブロックを構成する後段フィルタの带 域幅 $\omega_{2 c}$ は, 性能比較を考慮し, 文献(17)のロバスト PLL システムの PLL 帯域幅と同一に設計している。

実験結果を図 7 に示す。同図 (a) は，上から，位相真値 (破線表示) $\theta_{\alpha}$, 位相推定值 (実線表示) $\hat{\theta}_{\alpha}$, 次式で定義さ れた位相推定誤差 $\Delta \theta_{\alpha}$ の 20 倍值を示している。

$$
\Delta \theta_{\alpha}=\hat{\theta}_{\alpha}-\theta_{\alpha}
$$

位相真值と同推定值の表示は, 波形デー夕の重複・輻軼を さけるべく, $2(\mathrm{rad})$ 相当の原点シフトを行ない表示してい る(以下の位相表示も同様)。同図 (b) は周波数推定值 $\hat{\omega}_{\alpha}$ と振幅推定值 $\hat{V}$ とを示している。周波数推定值, 振幅推定 值のスケールは, 各々 $0.1(\mathrm{rad} / \mathrm{div}), 1(\mathrm{~V} / \mathrm{div})$ であり, 周波 数推定值に対し大スケールを利用している点には特に注意 されたい。なお，振幅推定值のスケールには，他のスケー ルとの区別のため, 単位 $(\mathrm{V})$ を付してある。図 (a), (b) の 時間軸は共に $0.05(\mathrm{~s} / \mathrm{div})$ である。

図より明らかなように，位相，周波数，振幅のいずれも 良好に推定されている。細部について見ると, 位相推定誤 差の最大值は約 $-0.0006(\mathrm{rad})$ であり, 次式で定義された周 波数相対誤差 $\delta \omega_{\alpha}$ の最大值は約 $-2.4 \times 10^{-4}$ であった。 


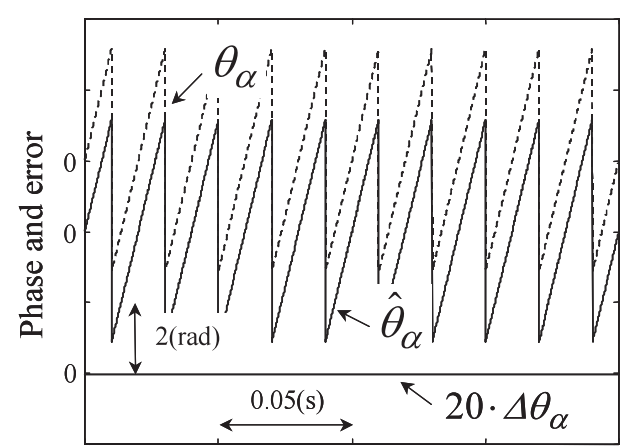

Time(s)

(a) Actual and estimated phases.

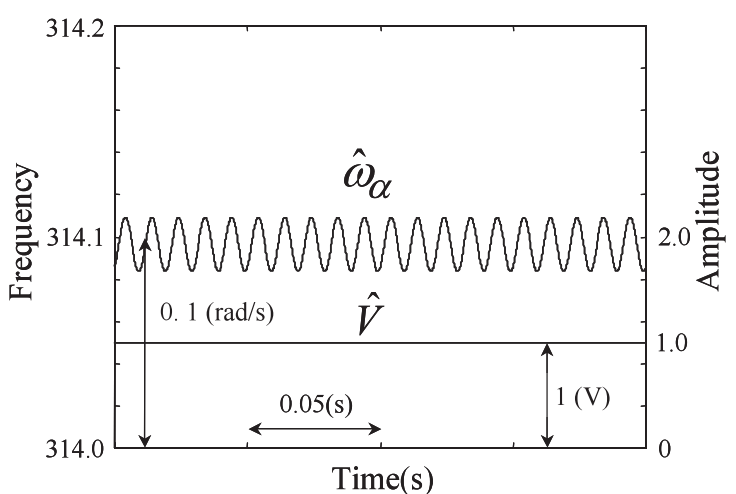

(b) Estimated amplitude and frequency

図 7 基本応答

Fig. 7. Basic responses to ideal signal.

$$
\delta \omega_{\alpha}=\frac{\hat{\omega}_{\alpha}-\omega_{\alpha}}{\omega_{\alpha}} .
$$

大スケールで明示したように，周波数推定值は単相信号の 基本周波数の 2 倍周波数 $(200 \pi(\mathrm{rad} / \mathrm{s}), 100(\mathrm{~Hz}))$ で振動 を起こしているが，振動振幅は十分に小さく，10-4 の相対 精度で推定されている（2 倍周波数の振動は, ローパスフィ ルタ $F_{\ell}(s)$ によるフィードバック効果によるものと推測さ れるが，解析は未完了である)。これら推定精度が示す，理 想的信号に対する定常性能に関しては，提案法はロバスト PLL 法には及ばないが(17)，高い推定精度が得られている。

$\langle\mathbf{5} \cdot \mathbf{2}\rangle$ 周波数変動に対する追従性能 提案の D 因子 推定法の最大特長は，推定原理をフィルタリングに置きな がらも，単相信号の基本周波数变動に追従して，位相，周波 数を正しく推定できる点にある。本性能を確認すべく, (28) 式に代わって次の条件を付した単相信号を用意した ${ }^{(17)}$ 。

$$
\omega_{\alpha}=100 \pi(1+0.1 \sin (20 t)), \quad \phi_{\alpha}=0, \quad e=0
$$

すなわち，変動幅 $\pm 10 \%$, 変動周波数 $20(\mathrm{rad} / \mathrm{s})$ の周波数変 動をもつ信号を用意した。本変動は, 基本周波数の変動と しては極めて大きいものである ${ }^{(9) \sim(17)}$

システム設計は，〈5·1〉節の基本性能の場合と同一の (29) 式とした。実験結果を図 8 に示す。同図 (a) は時間 軸 0.05 (s/div) で位相真值（破線） $\theta_{\alpha}$, 同推定值 (実線) $\hat{\theta}_{\alpha}$,

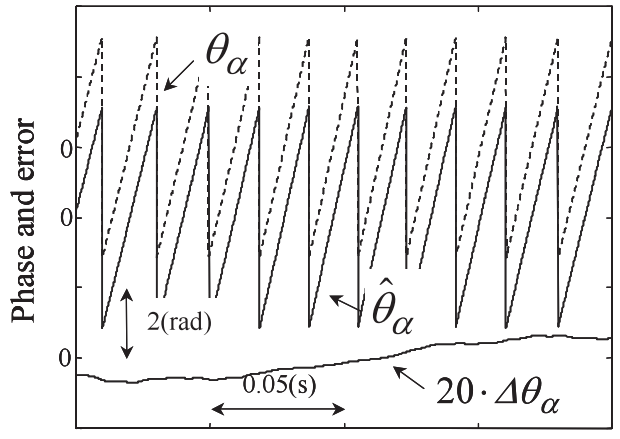

Time(s)

(a) Actual and estimated phases

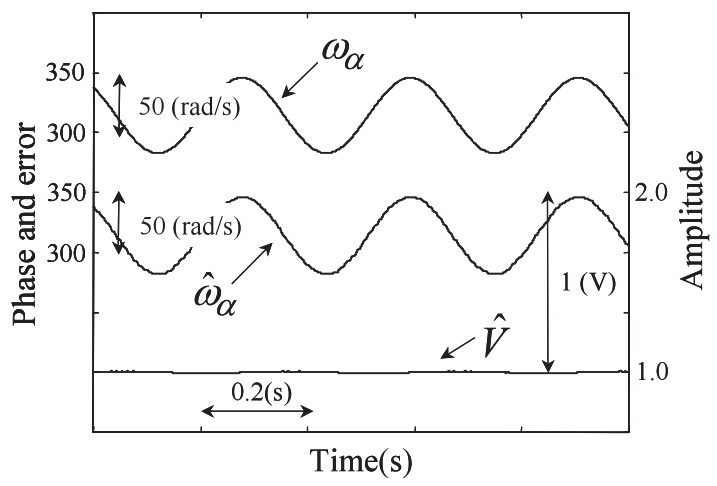

(b) Actual, estimated frequencies and estimated amplitude.

図 8 周波数変動に対する応答

Fig. 8. Responses to frequency-varying signal.

位相推定誤差 $\Delta \theta_{\alpha}$ の 20 倍值を，(b) は時間軸 $0.2(\mathrm{~s} / \mathrm{div})$ で 周波数真值 (破線) $\omega_{\alpha}$, 同推定值 (実線) $\hat{\omega}_{\alpha}$ 及び振幅推 定值 $\hat{V}$ を示している。周波数の推定は, その変動にもかか わらず，極めて良好である。位相，振幅の推定も同様に良 好である。所期の周波数変動に追従した推定が達成されて いることが確認される。図 8 に示されたような周波数追従 性能は, 一定基本周波数を前提とするフィルタリングに原 理をおく推定法（フィードバックフィルタ法, 写像法など） では得ることができない(1)(2)。また，本推定法の位相推定性 能はロバストPLL 法より多少良好であり, 周波数変動に対 する本推定法の追従性能は，ロバストPLL 法より少々高い ようである ${ }^{(17)}$ 。

〈5・3〉 位相跳躍に対する追従性能 単相信号の位相 跳躍 (phase jump) に対する提案 D 因子推定法の性能を確 認すべく, ある瞬時に, 大きな位相跳躍 $\phi_{\alpha}=\pi / 2(\mathrm{rad})$ を もつ単相信号を用意した ${ }^{(17)}$ 。単相信号の条件は，位相跳躍 以外は，(28) 式と同一である。実験結果を図 9 に示す。同 図 (a) は時間軸 0.05 (s/div) で位相真值, 同推定值及び位相 推定誤差を示している。位相推定誤差から理解されるよう に，位相推定值は位相跳躍後約 $0.03(\mathrm{~s})$ という短時間で再 収斂を概ね完了している ${ }^{(17)}$ 。同図 (b) は，時間軸 0.2 (s) で 跳躍位相, 周波数推定值, 振幅推定值を示している。周波 数推定值は, その上下限が真值の $\pm 10 \%$ に抑えられている が，これはリミッタの効果による (図 6 参照)。振幅推定值 


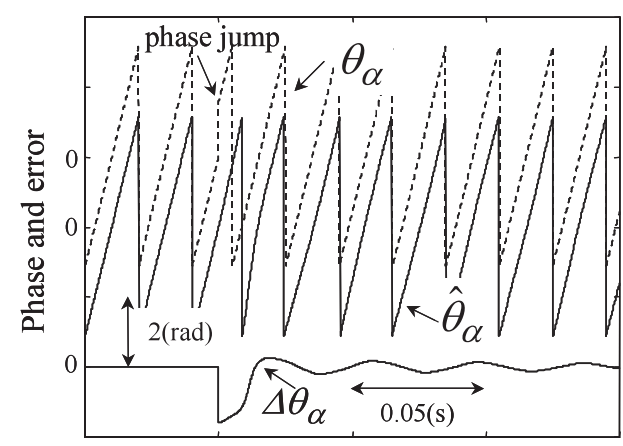

Time(s)

(a) Actual and estimated phases.

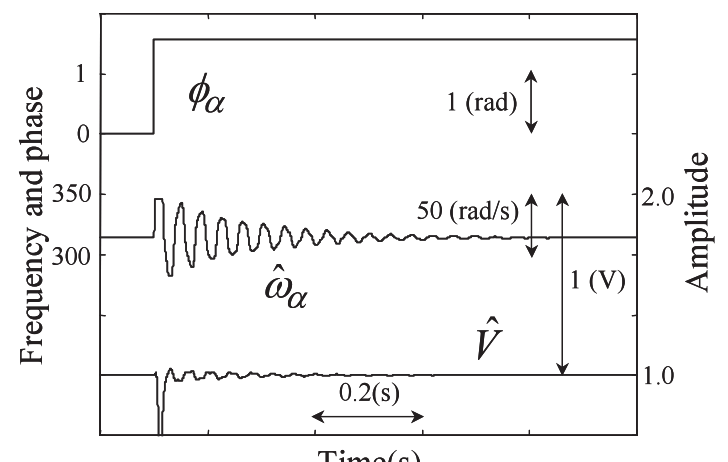

(b) Jumping phase, estimated frequency and amplitude.

図 9 位相跳躍に対する応答

Fig. 9. Responses to signal with phase jump.

は，位相跳躍直後に，大きな跳躍が見受けられるが，位相 推定值同様に急速に真值へ収斂している。

なお，周波数追従機能をもつPLL 法の中で最高レベルの 性能を有するロバスト PLL 法は，同様の位相跳躍に対し， 再収斂に約 $0.1(\mathrm{~s})$ を要しており (17)，位相跳躍に対する性能 に関しては，D因子推定法は，ロバスト PLL 法を優に超え ているようである。

〈5・4 振幅変動に対する追従性能 単相信号の振幅変 動に対する提案 D 因子推定法の性能を確認すべく，ある瞬時 に，基準值対し 50\%の瞬時振幅減少（50\% sag）と 150\%の 瞬時振幅増加（150\% swell）をもつ単相信号を用意した ${ }^{(17)}$ 。 振幅を除く他の条件に関しては，(28) 式と同一である。実 験結果を図 10 に示す。同図 (a) は時間軸 0.05 (s/div) で位 相真值, 同推定值及び位相推定誤差の 20 倍值を, 同図 (b) は時間軸 $0.2(\mathrm{~s})$ で周波数推定值, 振幅真値, 振幅推定値を示 している。振幅 $V$ は， $1 \rightarrow 0.5 \rightarrow 1.5$ と瞬時変化させた。図 (a) は，瞬時振幅減少 $(1 \rightarrow 0.5)$ 時のものであるが, 位相推 定は，振幅変動の影響をほとんど受けていないことが確認 される。瞬時振幅増加 $(0.5 \rightarrow 1.5)$ 時の位相推定も同様で あった。なお，本振幅増加は，相対的には $300 \%$ 瞬時増加に 相当する点には, 注意されたい。周波数推定值は, 入力さ れた単相信号に起因した周期 0.04 (s) の脈動をもつが，平 均值は安定している。また，振幅推定は，真值と推定值の 比較より明らかなように，高速推定に成功している。

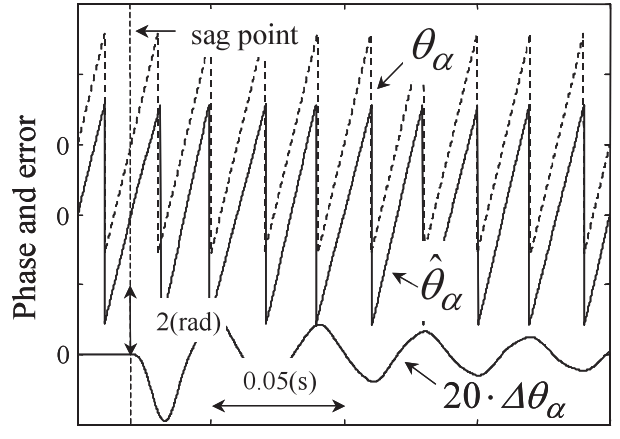

Time(s)

(a) Actual and estimated phases

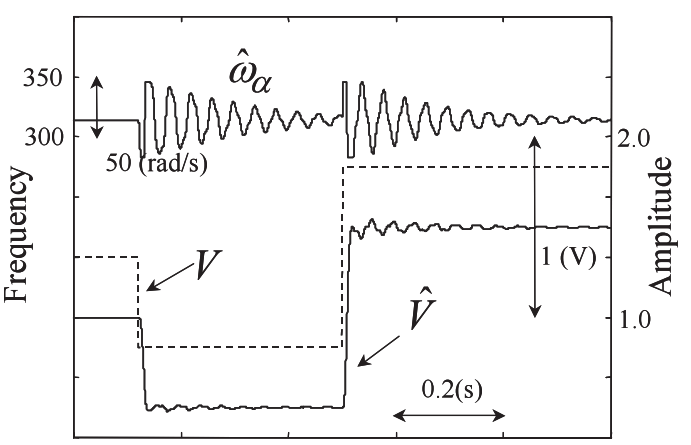

Time(s)

(b) Estimated frequency and actual and estimated amplitudes.

図 10 振幅変動に対する応答

Fig. 10. Responses to signal with amplitude sag and swell.

振幅の瞬時変動に対する位相推定值，振幅の追従性能に は，D因子推定法とロバスト PLL 法の間には，特筆すべき 差は見られない。周波数推定值の振動幅に関しては，D因 子推定法はロバスト PLL 法に倍する值を示している。振幅 変動に関する追従性に関しては, D 因子推定法はロバスト PLL 法にわずかながら劣るようである(17)。

〈5.5〉信号歪みに対する性能 単相信号の歪みに対 する提案 D 因子推定法の性能を確認すべく, 振幅 \pm 1 の矩 形状の単相信号を用意した ${ }^{(17)}$ 。本矩形信号は振幅 $V=4 / \pi$ の基本波成分と高調波成分 $e$ からなり，高調波成分による 極めて高い歪み $(48.3 \%$ THD）を有している。本信号の歪 み以外の条件は，(28)式と同一である。

単相信号が有する高調波歪みを考慮し，D因子フィル夕 ブロック，ローパスフィルタ $F_{\ell}(s)$ の設計パラメータは, (17b) 式，(25b) 式に従い，以下のように再設計した。

$$
\left.\begin{array}{l}
a_{1,0}=200 \pi, \quad \omega_{2 c}=30, \\
\omega_{n}=1.55 \omega_{2 c}=46.5, \quad \omega_{\ell c}=\omega_{2 c}=30
\end{array}\right\}
$$

なお，D因子フィルタブロックを構成する後段フィルタの带 域幅 $\omega_{2 c}$ は, 性能比較を考慮し, 文献 (17) のロバスト PLL システムの PLL 帯域幅と同一に設計している。

実験結果を図 11 に示す。同図 (a) は時間軸 $0.02(\mathrm{~s} / \mathrm{div})$ で入力の単相信号と位相推定值を, 同図 (b) は時間軸 0.2 (s) で周波数推定值と振幅推定値を示している。基本波成分に 


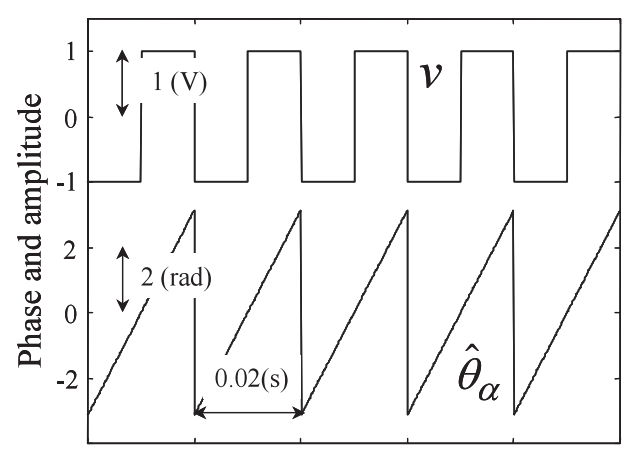

Time(s)

(a) Input signal and estimated phase.

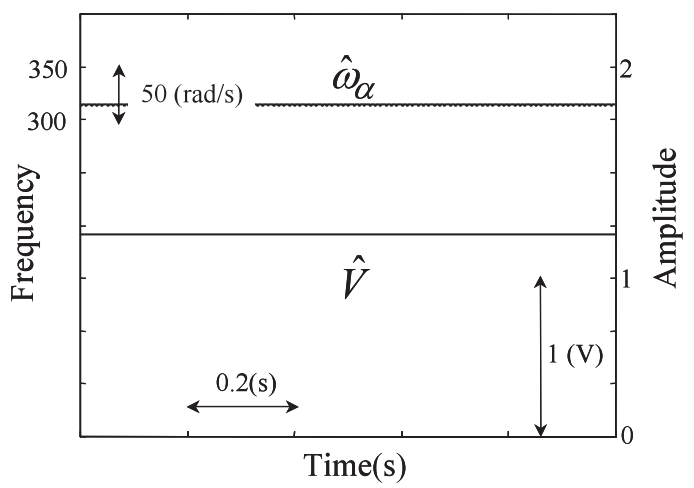

(b) Estimated frequency and amplitude.

図 11 矩形信号 (48.3\%THD) に対する応答

Fig. 11. Responses to rectangular signal with $48.3 \%$ THD.

関する位相, 周波数, 振幅は, 共に, 良好に推定されてい ることが確認される。特に，振幅推定值は，ロバスト PLL 法において見られた脈動が, 実質的には消滅していること が確認される。

信号歪みに対する推定に関しては，D 因子推定法は，D 因子フィルタが有する高周波成分の抑圧機能，波形整形機 能の特長を活かすことができ，ロバスト PLL 法を超える性 能を発揮できるようである(17)。

〈5・6〉ノイズ抑圧の性能ノノイズに対する提案 D 因 子推定法の性能を確認すべく，ノイズを有する単相信号を 用意した。ノイズ $e$ は， \pm 0.5 の間で一様に分布した白色ノ イズとした ${ }^{(17)}$ 。単相信号基本波成分の振幅 $V=1$ を考慮 すると，本ノイズレベルは極めて高いと言える。本信号の ノイズ以外の条件は，(28) 式と同一である。また，D因子 フィルタブロック，ローパスフィルタの設計は, (33) 式と 同一である。

実験結果を図 12 に示す。同図 (a) は時間軸 0.05 (s/div) で，位相真值，同推定值及び位相推定誤差の 20 倍值を，同

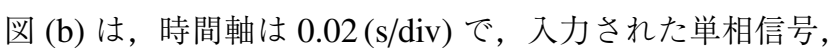
周波数推定值，振幅推定值を示している。高いノイズレベ ルにもかかわらず，位相，周波数，振幅ともノイズの影響 をほとんど受けず適切に推定されている。

特にロバスト PLL 法と比較した場合，位相推定誤差の微 小さが際立っており，推定原理をフィルタリングにおく D

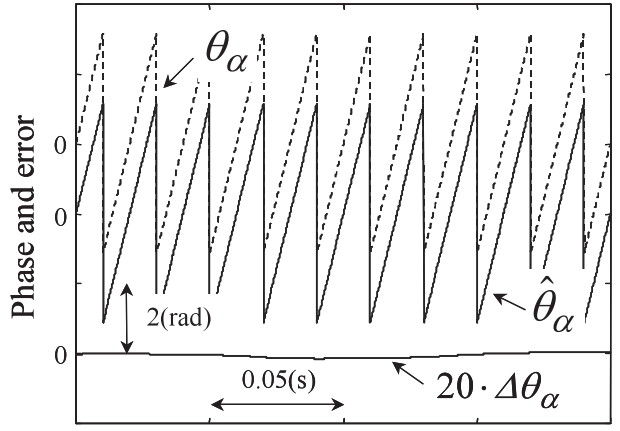

Time(s)

(a) Actual and estimated phases.

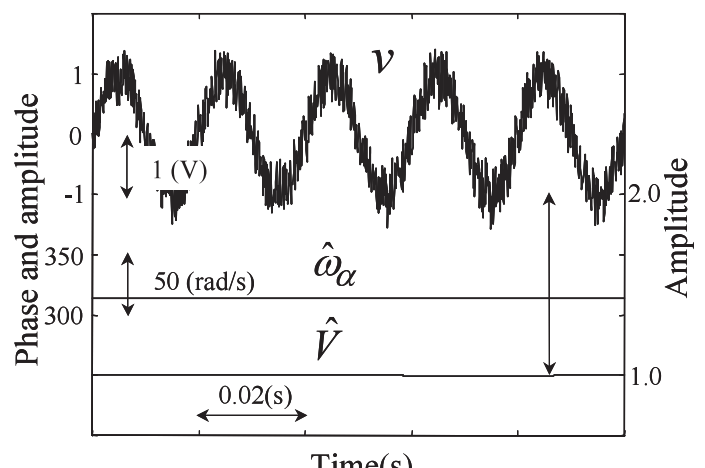

(b) Input signal, estimated frequency and amplitude.

図 12 ノイズを含む信号に対する応答

Fig. 12. Responses to signal contaminated by noise.

因子推定法の特長が顕著に出現している ${ }^{(17)}$ 。

$\langle\mathbf{5} \cdot \mathbf{7}\rangle$ 過渡応答の例 過渡応答の性能を, ロバスト PLL 法と比較により検討した。システムの条件は, $\langle 5 \cdot 2\rangle$ 節 （周波数変動に対する追従性能）の場合と同一である ${ }^{(17)}$ 。 図 13 は，推定開始直後の過渡応答を示したものである。同 図 (a)，(b) の波形の意味は，定常応答を示した図 8 と同一 である。

図より明らかなように，推定值は，推定開始後約 $0.08(\mathrm{~s})$ で収斂を完了し, 定常状態に入っている。ロバスト PLL 法 が定常状態への突入に $0.5 〜 1.0(\mathrm{~s})$ を要している点を考慮 するならば, 提案の D 因子推定法は, 推定開始の過渡応答 に関しては，約 10 倍近い速応性を達成している ${ }^{(17)}$ 。

\section{6. おわりに}

本論文は, 周波数変動を伴う単相信号の位相, 周波数, 振 幅の瞬時推定を目的とした推定法として，フィルタリング に原理を置く D 因子推定法を，設計パラメー夕の具体的設 計法と共に新規に提示し, 周波数変動に対する追従性能, 位 相跳躍に対する追従性能, 振幅変動に対する追従性能, 信 号歪みに対する性能, ノイズ抑圧の性能の観点から, その 推定性能を数值実験通じ検証・確認した。この際, 実験条 件はロバスト PLL 法と実質同一とし，これとの性能比較も 行った。実験結果によれば，個々の性能に関しては多少の 優劣が存在するが, 総合的には, D 因子推定法はロバスト 


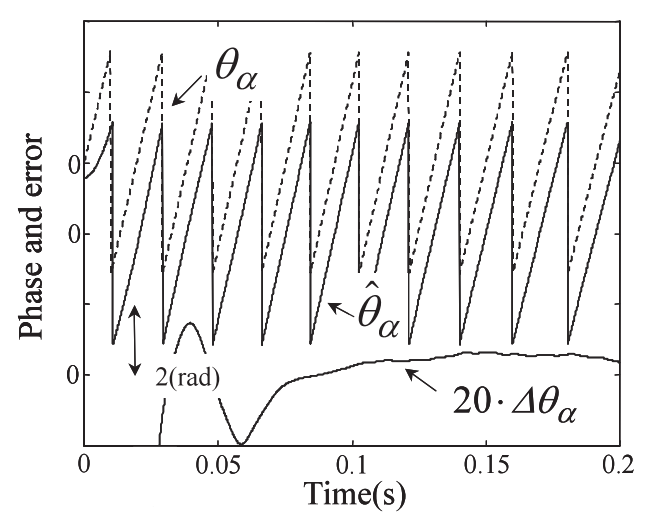

(a)

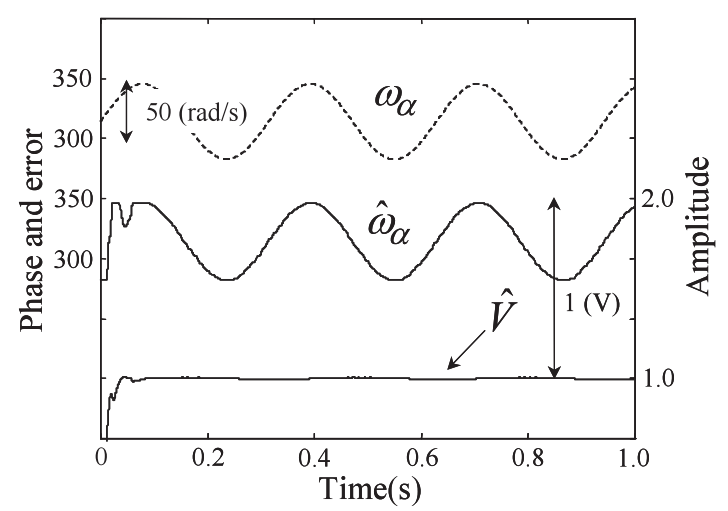

(b)

図 13 周波数変動信号に対する過渡追従性

Fig. 13. Transient responses to frequency-varying signal.

PLL 法と同等の実用性能を有することを確認した。

「周波数変動を伴う単相信号に対しフィルタリングに原理 を置く推定法が適用可能である」ことを新規に立証し，更 には，ロバスト PLL 法と同等の実用性能を有する D 因子 推定法の今後の活用が期待される。

(平成 20 年 4 月 12 日受付, 平成 20 年 10 月 5 日再受付)

$$
\text { 文献 }
$$

(1) S. Shinnaka: "A Simple Instant-Estimation Method for Time-Average Quantities of Single-Phase Power and Applications to Single-Phase Power Grid Connection by Inverter", IEEJ Trans. PE, Vol.124, No.11. pp.1327-1335 (2004-11) (in Japanese)

新中新二:「単相電力に扔ける周期的時間平均量の簡易瞬時推定法と単 相電力系統連系への応用」, 電学論 B, 124, 11, pp.1327-1335 (2004-11)

(2) S. Shinnaka: "A New Mapping Method for Phase-Estimation of SinglePhase Signals-A New Generation and New Realizations of the DFT Estimation Method-", IEEJ Trans. PE, Vol.125, No.1. pp.29-38 (2005-1) (in Japanese)

新中新二：「写像法による単相信号の瞬時位相推定一DFT 法の一般 化と実現—」, 電学論 B, 125, 1, pp.29-38 (2005-1)

(3) A.G. Phadke, J.S. Thorp, and M.G. Admiak: "A New Measurement Technique for Tracking Voltage Phasors, Local System Frequency, and Rate of Change of Frequency", IEEE Trans. Power Apparatus and Systems, Vol.102, No.5, pp.1025-1033 (1983-5)

(4) J.A. de la O, H.J. Altuve, and I. Diaz: "A New Digital Filter for Phase Computation, Part I: Theory", IEEE Trans. Power Systems, Vol.13, No.3, pp.1026-1031 (1998-8)

( 5 ) H.J. Altuve, I. Diaz, and J.A. de la O: "A New Digital Filter for Phase Computation, Part II: Evaluation", IEEE Trans. Power Systems, Vol.13, No.3, pp.1032-1037 (1998-8)
(6) T. Funaki, K. Matsuura, and S. Tanaka: "Error Estimation and Correction of Detected Phase by Real Time DFT", IEEJ Trans. PE, Vol.120, No.12, pp.1682-1690 (2000-12) (in Japanese)

舟木 剛・松浦虔士 ·田中俊輔：「DFT 実時間位相推定の誤差評価 と補正法」, 電学論 B, 120, 12, pp.1089-1090, pp.1682-1690 (2000-12)

7 T. Funaki, K. Matsuura, and S. Tanaka: "Error Correction for Phase Detection by Recursive Algorithm Real Time DFT", IEEJ Trans. PE, Vol.121, No.9, pp.1085-1093 (2000-9) (in Japanese)

舟木 剛・松浦虔士・田中俊輔：「再州的アルゴリズムを用いた実時 間 DFT 位相推定の誤差対策」, 電学論 B, 121, 9, pp.1085-1093 (2000-9)

8 ) M. Saitou and T. Shimizu: "A Novel Control Method on Single Phase Grid Connectable Inverter with Hilbert Transformer", IEEJ Trans. IA, Vol.121, No.10, pp.1089-1090 (2001-10) (in Japanese)

齋藤 真・清水敏久:「ヒルベルト変換を用いた単相系統連系イン バータの制御法，単相電流の d-q 座標での制御」, 電学論 D, 121, 10, pp.1089-1090 (2001-10)

(9) M. Karimi-Ghartemani and M.R. Iravani: "A Nonlinear Adaptive Filter for Online Signal Analysis in Power System: Applications", IEEE Trans. Power Delivery, Vol.17, No.2, pp.617-622 (2002-4)

(10) P. Rodriguez, A. Luna, M. Ciobotaru, R. Teodorescu, and F. Blaabjerg: "Advanced Grid Synchronization System for Power Converters under Unbalanced and Distorted Operating Conditions", Proc. of 32nd IEEE International Conference on Industrial Electronics, Control, and Instrumentation (IECON 2006), pp.5173-5178 (2006-11)

(11) L.N. Arruda, B.J.C. Filho, S.M. Silva, S.R. Silva, and A.S.A.C. Diniz: "Wide Bandwidth Single and Three-Phase PLL Structures for Grid-Tied PV Systems", Record of the 28th IEEE Photovoltaic Specialist Conference 2000, pp.1660-1663 (2000)

(12) S.M. Silva, L.N. Arruda, and B.J.C. Filho: "Wide Bandwidth Single and Three-Phase PLL Structures for Utility Connected Systems", CD-Proc. of 9th European Conference on Power Electronics and Applications (EPE 2001) (2001-8)

13) L.N. Arruda, S.M. Silva, and B.J.C. Filho: "PLL Structures for Utility Connected Systems", Conference Record of the 2001 IEEE Industry Applications Conference, 36th IAS Annual Meeting (IAS 2001), Vol.4, pp.26552660 (2001-9)

(14) S.M. Silva, B.M. Lopes, B.J.C. Filho, R.P. Campana, and W.C. Boaventura: "Performance Evaluation of PLL Algorithms for Single-Phase GridConnected Systems", Conference Record of the 2004 IEEE Industry Applications Conference, 39th IAS Annual Meeting (IAS 2004), Vol.4, pp.22592263 (2004-10)

(15) M. Ciobotaru, R. Teodorescu, and F. Blaabjerg: "Improved PLL structures for single-phase grid inverters", CD-Proc. of International Conference on Power Electronics and Intelligent Control for Energy Conservation (PELINCEC2005) (2005-10)

(16) M. Ciobotaru, R. Teodorescu, and F. Blaabjerg: "A New Single-Phase PLL Structures Based on Second Order Generalized Integrator", CD-Proc. of 37th IEEE Power Electronics Specialist Conference (PESC 2006) (2006-6)

(17) S. Shinnaka: "A Robust Single-Phase PLL System with Stable and Fast Tracking", IEEE Trans. on Industry Applications, Vol.44, No.2, pp.624-633 (2008-3/4)

（18）新中新二：「永久磁石同期モータのベクトル制御技術・上巻（基礎か ら最先端まで)」,電波新聞社, pp.283-348 (2008)

新 中 新 二 (正員) 1973 年防衛大学校卒業。同年陸上自衛

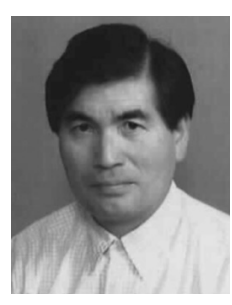
隊中央野外通信群入隊。1977 年 University of California，Irvine 大学院修士課程修了。1979 年同博 士課程修了。防衛庁技術研究本部第 1 研究所，防 衛大学校電気工学教室等での奉職を終えて, 1986 年陸上自衛隊を除隊。同年キヤノン (株) 勤務。 1991 年ベンチャー研究所創設。1996 年神奈川大 学電気工学科勤務（教授, 現電子情報フロンティ ア学科)。2002 年同学市民 EV センター創設。これまでの間, 通信, 情報, 制御, パワーエレクトロニクス分野の教育, 研究, 開発及びこれ らの管理等に従事。計測自動制御学会全 3 賞（論文賞，著述賞，技術 賞), IEEE IAS-Transactions 論文賞を受賞。計測自動制御学会, IEEE, 自動車技術会などの会員。Doctor of Philosophy 及び工学博士。 